\title{
ДОСТУП МИГРАНТОВ К СОЦИАЛЬНЫМ УСЛУГАМ В РОССИИ НА ПРИМЕРЕ ГРАЖДАН АЗЕРБАЙДЖАНА
}

В статье анализируется уровень доступности социальных услуг для мигрантов из Азербайджана в России, а также изменения этого уровня в связи с новациями в миграционном законодательстве 2013-2016 гг. В качестве основных индикаторов анализа выбраны: легальность и условия труда, медицинские услуги, образование детей, жилищные условия азербайджанских мигрантов в сравнении с мигрантами из других стран СНГ. Эмпирическую базу исследования составили данные всероссийских социологических опросов трудовых мигрантов Центра этнополитических и региональных исследований для НИУ-ВШЭ в 2011 и 2017 гг. Также использованы данные полуструктурированных интервью с экспертами, информация из открытых источников о законодательном регулировании миграции. Исследование показало, что мигранты из Азербайджана, являясь одной из наименее легализованных групп на российском рынке труда, имеют тот же уровень доступа к социальным услугам, что и мигранты из других стран СНГ. Из-за высокого уровня неформальной занятости распространены случаи нарушения их трудовых прав, они не могут быть защищены в полной мере. Однако, ввиду высокой в сравнении с другими мигрантами платежеспособности, азербайджанцы имеют равный либо лучший доступ к медицинскому обслуживанию, образованию детей и жилищным условиям. Во-первых, они чаще других готовы обращаться за платными медицинскими услугами. Во-вторых, у азербайджанских мигрантов шире доступ к детским дошкольным учреждениям в России в сравнении с выходцами из Средней Азии, а к общеобразовательным учреждениям- на таком же уровне, как и у других мигрантов. В-третьих, азербайджанцы больше, чем другие группы мигрантов обеспечены отдельным жильем, в том числе собственным. Делается вывод о том, что в 2017 г. по сравнению с 2011 г.

Анна Александровна Эндрюшко-мл.н.с., Институт социологии, Федеральный научноисследовательский социологический центр Российской академии наук, Москва, Россия. Электронная почта: anna.endryushko@mail.ru 
доступ мигрантов в целом, в том числе и азербайджанцев, к социальным услугам улучшился. Часть этих изменений связана с поправками в миграционное законодательство 2013-2016 гг.

Ключевые слова: трудовые мигранты, азербайджанцы, социальные услуги для мигрантов, миграционное законодательство

DOI: $10.17323 / 727-0634-2020-18-4-689-704$

Уязвимое положение иммигрантов в принимающих странах определяется набором факторов, в числе которых языковой барьер, культурные различия, практики дискриминации различного уровня, особенности миграционного законодательства. Эти факторы оказывают существенное влияние не только на экономическое положение иностранцев и их семей, но и на доступ к получению необходимых социальных услуг. Некоторые европейские страны привлекают поток мигрантов широким набором доступных социальных благ (Mingot, Mazzucato 2019: 140). Однако в последние годы доступ к ним становится все более затрудненным. В Россию мигранты приезжают в основном с целью заработка, и зачастую такие важные социальные права как охрана здоровья, благоприятные условия труда, образование детей отходят на второй план. Число иностранных граждан и лиц без гражданства, постоянно находящихся на территории РФ, оценивается в 9,2-11,8 млн человек (Мукомель 2017: 69). Многие из них, в т.ч. несовершеннолетние, прибывающие в страну с родителями, лишены доступа даже к минимальному, гарантированному российским и международным законодательством социальному обслуживанию.

В российских исследованиях, посвящённых социальной политике в отношении мигрантов изучаются вопросы медицинского обслуживания (Kashnitsky, Demintseva 2018; Кузнецова, Мухарямова 2014), образования для детей (Тюрюканова, Леденева 2005; Омельченко 2018), жилищных условий (Бредникова, Ткач 2010), положения на российском рынке труда (Карачурина 2005; Мукомель 2017). Однако редко рассматривается уровень доступности социальных услуг именно для мигрантов из Азербайджана, в том числе в сравнительной перспективе. В этой статье на примере азербайджанцев рассматривается изменение доступа к социальным услугам для трудовых мигрантов в 2011 и 2017 гг. на основе данных всероссийских опросов, а также анализируется связь изменений с поправками в миграционное законодательство, принятыми в рассматриваемый период (см.: Григорьева, Мукомель 2016a; 2016b).

Доступность социальных услуг для мигрантов из Азербайджана определяется рядом географических, политических, правовых, социальных факторов. Так, Азербайджан не входит в Евразийский экономический союз (ЕАЭС), и азербайджанские мигранты не обладают преимуществами, доступными гражданам стран-участниц союза. К последним относятся 
увеличенный срок постановки на миграционный учёт (30 дней вместо семи), возможность работать в России без патента, право оформления полиса обязательного медицинского страхования. Кроме того, Азербайджан входит в число миграционных доноров России. На протяжении 2011-2017 гг. в Россию ежегодно прибывало 20-25 тысяч азербайджанских мигрантов; в 2017 г. на территории РФ находились около 520 тыс. граждан Азербайджана (Росстат 2017). Ввиду длительного и стабильного опыта миграции, азербайджанцы имеют прочные семейные и дружеские связи в России и их накопленный социальный капитал может оказывать положительное влияние на доступ к социальному обслуживанию в принимающей стране. Социальный капитал (прежде всего, социальные связи) считается важным фактором успешной интеграции (Aguilera, Massey 2003; Татарко 2018).

Доступ мигрантов к социальному обслуживанию рассматривается в статье через индикаторы, наиболее часто использующиеся в исследованиях европейских стран. Так, голландские (Entzinger, Biezeveld 2003; Penninx 2019) и немецкие (Esser 2004) ученые, концептуализируя параметры оценки социально-экономической сферы включения мигрантов в принимающее общество, апеллируют в первую очередь к доступу мигрантов к сфере занятости, к социальным институтам поиска жилья, образования, здравоохранения. Для этого анализа выбраны сходные параметры оценки социального обслуживания мигрантов в России-условия труда и его легальность, доступ к образованию детей, к медицинским услугам, жилищные условия мигрантов. При рассмотрении положения мигрантов из Азербайджана, также приводятся сравнения с мигрантами из других стран СНГ, в случаях, где имеются наиболее заметные различия.

В качестве эмпирической базы использованы данные всероссийского социологического исследования трудовых мигрантов НИУ ВШЭ, проведенного в конце 2011 г. Центром этнополитических и региональных исследований (ЦЭПРИ). Объем выборочной совокупности- 8499 мигрантов в восьми регионах России. Азербайджанцев в выборке-270. А также данные исследования НИУ ВШЭ, полученные на основе опроса 2017 г. Это обследование проводилось в 19 субъектах РФ, опрашивались граждане стран СНГ независимо от их правового статуса. Общий объем выборочной совокупности - 8577 респондентов, азербайджанцев в выборке- 388. Наконец, работа дополняется данными полуструктурированных интервью с экспертами: представителями УВМ МВД России по г. Москве; страховых компаний, выпускающих полисы ДМС для иностранцев; общественных и правозащитных организаций, работающих с мигрантами; организаций, предоставляющих консалтинговые и юридические услуги иностранным работникам и их работодателям. Собрано 20 интервью и блиц-опрос 14 посреднических организаций, оказывающих иностранцам содействие в оформлении разрешительных документов. 


\section{Легальность пребывания и работы мигрантов}

Доступ мигрантов к социальным услугам в РФ обеспечивается российским и международным законодательством. Право на труд, его благоприятные условия и на отдых гарантированы Конституцией РФ (1993: ст. 37), Международным пактом об экономических, социальных и культурных правах (1996: ст. 6, 7), Европейской социальной хартией (1996: ст. 1, 2 п.1, 3-7, 3,4). Эти нормы касаются иностранных граждан, находящихся на территории России в урегулированном статусе, отсутствие которого (даже частичное) обусловливает их уязвимое положение. Основные сферы занятости азербайджанцев- оптовая и розничная торговля, гостиницы и рестораны, транспорт и связь, предоставление услуг (Эндрюшко 2018:223). Как правило, в этих сегментах занятости работодатели не оформляют сотрудников официально, особенно иностранных (Мукомель 2017: 74).

В 2011 г. разрешение на работу имели 58\% азербайджанских мигрантов, это меньше, чем у выходцев из Таджикистана $(64,1 \%)$, Узбекистана (63\%) и Украины (62\%). Патент был у $20 \%$ азербайджанцев, у 17,5\% киргизов, 12,5\% таджиков, 12\% узбеков и 6,6\% украинцев. В 2017 г., когда для мигрантов из СНГ появилась процедура получения патента (Федеральный закон 2014a), его имели 51,6\% мигрантов из Азербайджана (без учета тех, у кого имелись разрешение на временное проживание или вид на жительство). Как и в случае с разрешениями на работу в 2011 г., это меньше, чем среди других мигрантов (исключая приезжих из странучастниц ЕАЭС, которым не нужно оформлять патент)- 69,1% граждан Таджикистана и 70,3\%- Узбекистана.

Одной из целей поправок к миграционному законодательству, принятых в 2014 г., было снижение административных барьеров и коррупционных рисков в миграционной сфере путем замены разрешений на работу патентами (Пояснительная записка 2014). В результате этого нововведения упразднена система квотирования, что, в целом, положительно оценивалось экспертами. Однако новая патентная система создала и множество новых проблем, как для работодателей, так и для трудовых мигрантов. Процедуры оформления разрешительных документов значительно подорожали. Работодатели были вынуждены многократно продлевать постановку на учёт иностранных работников и одновременно отслеживать оплату ими патентов. По словам экспертов, такое усложнение правил миграционного учета вкупе с большими штрафами за его нарушение привело к отказу части работодателей от официального оформления трудовых мигрантов:

Иметь дело с иностранными гражданами официально все боятся... Если вы не уведомили вовремя, не отправили трудовой договор, не уведомили о расторжении трудового договора и так далее (Представитель общественной организации 1 , работающей с мигрантами). 
Самих мигрантов, как считают эксперты, высокая стоимость патента подталкивает к даче взяток в случае проверки документов: «Mигранть сейчас говорят, что лучше я каждому менту на улице дам две тысячи... Это дешевле оказывается» (Представительница общественной организации 2, работающей с мигрантами). Приобретение патента не гарантирует мигрантам полную легализацию в случаях, когда принимающая сторона (собственник жилья) отказывается ставить его на обязательный миграционный учет, выступающий одним из основных факторов урегулированного статуса. Опрос экспертов и блиц-опрос 14 посреднических организаций, показали, что иностранцы вынуждены оформлять «фиктивную» регистрацию из-за отказа арендодателя исполнять обязательства в данной области. Это подтверждается и многочисленными объявлениями в интернете, предлагающими оформление временной регистрации иностранным гражданам. А механизмы, обязывающие принимающую сторону ставить иностранца на миграционный учет, отсутствуют.

Изменение процедуры оформления разрешительных документов для работы в России и отказ в связи с этим части работодателей оформлять иностранных работников официально отражаются на правовом положении мигрантов. Доля азербайджанских мигрантов, незаконно работающих в России, составляет 38,1 \%. Это больше, чем среди других мигрантов: 26,5\% киргизов, 26,7\% армян, 33,1 \% узбеков, 32\% таджиков (2017 г.). Полученные данные позволяют сделать вывод о том, что в сравнении с другими мигрантами азербайджанцы наименее «легализованы». Это может обусловливать большую уязвимость в как в сфере занятости, так и в социальной сфере.

\section{Условия работы}

В 2017 г., по сравнению с 2011 г., среди азербайджанцев увеличилась доля тех, кто работает на основе устных договорённостей- с 35,4 до 50,9\%, а доля работающих по договору снизилась с 38 до 27,2\% (рис. 1). Отметим, что это характерно исключительно для мигрантов из Азербайджана. Среди других мигрантов ситуация обратная- уменьшение доли работающих на основе устных договоренностей и увеличение трудоустроенных на основании письменного договора (табл. 1).

Отсутствие разрешительных документов- одна из основных причин различия условий занятости между мигрантами из Азербайджана и другими группами мигрантов, так как 73,2\% азербайджанцев, не имеющих разрешительных документов, работают на неформальных основаниях (без письменного договора). Неформальной занятости также способствует распространённость трудоустройства у знакомых и родственников (Мукомель 2017: 74). Такой способ особенно характерен для торговли, основной сферы занятости азербайджанцев. Даже среди легализованных азербайджанских мигрантов более половины (59\%) работают без заключения трудового договора. 
Вы сейчас работаете (работали) на основе письменного договора устной договоренности или у Вас собственное дело?

60

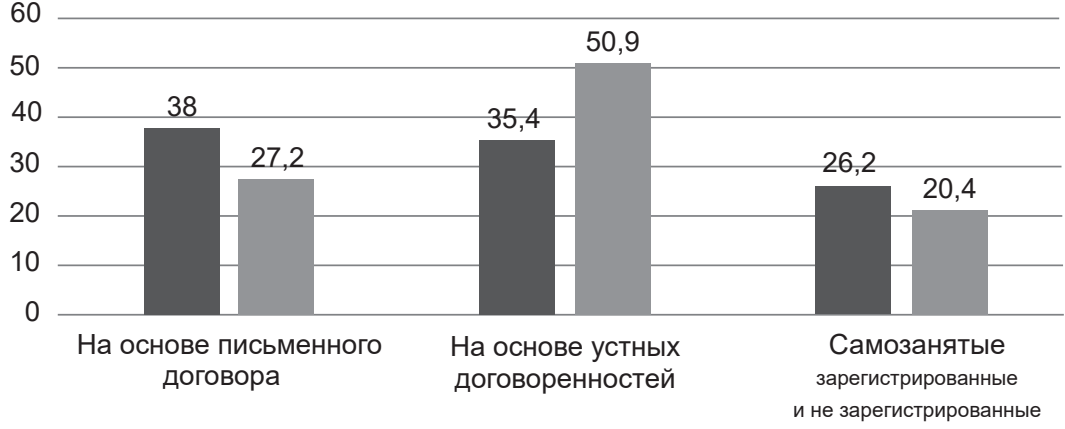

2011 год - 2017 год

Рисунок 1. Условия труда мигрантов из Азербайджана в 2011 и 2017 гг., в\% к опрошенным

Таблий 1

Условия труда отдельных групп мигрантов в России в 2011 и 2017 гг., в\% к опрошенным

\begin{tabular}{|c|c|c|c|c|}
\hline \multirow{3}{*}{ Страна исхода } & \multicolumn{4}{|c|}{$\begin{array}{c}\text { «Вы сейчас работаете на основе письменного } \\
\text { договора, устной договоренности ...?" }\end{array}$} \\
\hline & \multicolumn{2}{|c|}{$\begin{array}{c}\text { На основе письменного } \\
\text { договора }\end{array}$} & \multicolumn{2}{|c|}{$\begin{array}{l}\text { На основе устных } \\
\text { договоренностей }\end{array}$} \\
\hline & 2011 & 2017 & 2011 & 2017 \\
\hline Азербайджан & 38 & 27,2 & 35,4 & 50,9 \\
\hline Украина & 42,7 & 55,1 & 52,2 & 40,9 \\
\hline Армения & 27,7 & 47,7 & 50,7 & 38,1 \\
\hline Киргизия & 40,6 & 66,7 & 53,5 & 29,9 \\
\hline Таджикистан & 42,8 & 50 & 52,7 & 42,3 \\
\hline Узбекистан & 37,3 & 56,9 & 59,2 & 36,8 \\
\hline
\end{tabular}

У иностранных работников, как правило, более продолжительный рабочий день по сравнению с россиянами (Григорьева, Мукомель, 2014: 85). Азербайджанцы работают (по найму) в среднем 62,5 часа в неделю, в то время как представители Средней Азии - 60 часов, армяне- 57,5 часов, украинцы- 54,5 часов (2017 г.). Эти различия могут объясняться меньшим, по сравнению с другими иностранцами, доступом азербайджанцев к гарантиям в сфере занятости. Но есть и другие причины: стремление к вы- 
сокому заработку, готовность ради него жертвовать комфортными условиями жизни, отсутствие обременения повседневными семейными обязанностями для временных трудовых мигрантов (Григорьева, Мукомель, 2014: 85). При этом в целом доходы мигрантов невысоки и основная их часть не превышает 30 тыс. руб., но азербайджанцы по сравнению с выходцами из среднеазиатских стран шире представлены в группе с доходами свыше 50 тыс., и только среди азербайджанцев встречаются доходы, превышающие 100 тыс. руб. (табл. 2).

Таблица 2

Доходы некоторых групп мигрантов в России, в\% к опрошенным

\begin{tabular}{l|c|c|c|c|c|c}
\hline \multicolumn{1}{c|}{ Страна исхода } & $\begin{array}{c}\text { Среднее } \\
\text { значение } \\
\text { дохода }\end{array}$ & $\begin{array}{c}\text { до 30 } \\
\text { тыс. руб. }\end{array}$ & $\begin{array}{c}30-40 \\
\text { тыс. руб. }\end{array}$ & $\begin{array}{c}41-50 \\
\text { тыс. руб. }\end{array}$ & $\begin{array}{c}\text { Более 50 } \\
\text { тыс. руб. }\end{array}$ & $\begin{array}{c}\text { Выше } \\
\text { 100 тыс. } \\
\text { руб. }\end{array}$ \\
\hline Азербайджан & 34034 & 58,2 & 17,7 & 13,1 & 10,5 & 0,7 \\
Украина & 30561 & 59,8 & 19,3 & 12,6 & 10 & 0 \\
Армения & 30221 & 61,6 & 17,7 & 14 & 7 & 0 \\
Киргизия & 28938 & 69,8 & 21 & 6,4 & 1,1 & 0 \\
Таджикистан & 27020 & 75,7 & 16,3 & 6,1 & 2,3 & 0 \\
Узбекистан & 28485 & 74,3 & 17,7 & 5,9 & 1,8 & 0 \\
\hline
\end{tabular}

\section{Доступ к медицинским услугам}

Доступ мигрантов к медицинским услугам регулируется Постановлением Правительства РФ № 186 от 6.03.2013 г., согласно которому иностранные граждане на территории РФ имеют право на бесплатную медицинскую помощь в экстренной форме (при острых состояниях, несущих угрозу жизни) и в скорой. Это касается всех иностранных граждан, включая тех, кто не имеет разрешительных документов. Неотложная медицинская помощь, а также помощь в плановой форме осуществляются на основании договоров добровольного медицинского страхования (ДМС), обязательного медицинского страхования (ОМС), договоров об оказании платных медицинских услуг (Постановление Правительства РФ 2013). В январе 2015 г. вступил в силу Федеральный закон № 409-Ф3, установивший требование об обязательном медицинском страховании иностранных работников (Федеральный закон 2014б). Это повысило спрос на полисы ДМС, предлагаемые трудовым мигрантам, а также значительно снизило их стоимость. Изначально удешевление вызвано появлением на рынке большого количества недобросовестных компаний, предлагающих фактически фиктивные 
полисы, по которым было почти невозможно получить медицинскую помощь. В дальнейшем Указание Центробанка о требованиях к страховкам (2015) в значительной степени сократило предложение дешевых и некачественных полисов, тем самым скорректировав ситуацию на рынке медицинских услуг для мигрантов. Стоимость все равно осталась невысокой, поскольку в полис ДМС для трудовых мигрантов, как правило, включен минимальный набор медицинских услуг.

По словам экспертов, после принятия этих мер, доступ иностранных граждан к медицинскому обслуживанию в России несколько расширился. В 2017 г. у 41,5 \% мигрантов из Азербайджана имелся полис ДМС 1 . Впрочем, другие иностранцы оказались лучше обеспечены страховкой: 55,7\% таджиков и 64,1 \% узбеков заявили о наличии у них полиса ДМС. Мигранты из Киргизии, будучи гражданами стран-участниц ЕАЭС, имеют право на обязательное медицинское страхование, но у 44,3 \% из них имелся полис ДМС (среди белорусов, также имеющих право на ОМС, есть ДМС у $25,8 \%$, у армян-34,2\%). Мигранты из Азербайджана готовы пользоваться имеющейся у них страховкой- об этом сказали 27,1 \%. Но эта доля ниже в сравнении с другими мигрантами: $42,8 \%$ узбеков, $37,4 \%$ таджиков, $30 \%$ украинцев и 28,2\% киргизов заявили, что в случае необходимости обратятся за медицинской помощью по полису ДМС. Эксперты оценивают частоту обращений по страховым полисам как очень низкую- в районе 5-10\%. По их мнению, это связано с тем, что большинство мигрантов не умеют пользоваться страховым полисом и не знают какую помощь они могут получить, а некоторые, покупая полис в общем пакете документов, даже не догадываются о его существовании. Однако, по словам экспертов, количество обращений с момента введения обязательного медицинского страхования иностранных работников возросло и будет продолжать расти. Особую роль в этом играют национальные объединения и общественные организации, которые стараются просвещать иностранцев, работающих легально, об их правах на доступ к медицинскому обслуживанию: «Люди начинают понимать, их начинают просвещзать свои же, что у тебя есть полис, ты не просто так четыре тысячи заплатил» (представитель СПАО «РЕСО-Гарантия»).

Анализ данных опроса показывает, что по сравнению с 2011 г. в 2017 г. обращение за медицинскими услугами увеличилось. Снизилась доля тех, кто в случае болезни лечится самостоятельно; обращается к друзьям/родственникам; лечится на родине. Доля азербайджанских мигрантов, готовых пойти к врачу за платными услугами, снизилась, но остается сравнительно высокой- 50,3\% (в среднем по выборке среди других групп мигрантов выразили такую готовность не более $39 \%$ опрошенных). Таким образом, меньшую обеспеченность полисами ДМС мигранты-азербайджанцы ком-

\footnotetext{
${ }^{1}$ В исследовании 2011 г. вопрос о наличии полиса ДМС не задавался.
} 
пенсируют высокой платежеспособностью. С учетом небольшого набора услуг, доступного для большинства полисов ДМС, оформляемых иностранцами, можно заключить, что азербайджанцы, по меньшей мере, не проигрывают в доступе к медицинской помощи другим мигрантам.

\section{Доступ к образовательным учреждениям}

Конституция РФ гарантирует право каждого на общедоступность и бесплатность дошкольного, основного общего и среднего профессионального образования (ст. 47). А иностранные граждане, в соответствии Федеральным законом «Об образовании» (2012) обладают равными с гражданами РФ правами на получение дошкольного, начального общего, основного общего и среднего общего образования (ст. 78). То есть нелегальное положение родителей, согласно конституционной норме и федеральному закону, не должно влиять на возможность получения их детьми образования. Однако Приказ Министерства образования и науки № 32 от 22.01.2014 (2014) разрешает зачислять детей иностранных граждан в школу только при наличии документов о постановке на миграционный учет и иных необходимых разрешительных документов.

Для мигрантов из Азербайджана (как и других представителей Закавказья) характерна «семейная миграция»- более $60 \%$ респондентов (2017 г.) живут в России с членами семьи. «Одиночная» миграция в большей степени свойственна приезжим из государств Средней Азии- из Узбекистана (64\%) и Таджикистана (59\%). При этом 61 \% азербайджанских мигрантов состоят в браке (включая зарегистрированный, религиозный, гражданский), у 41 \% есть дети младше 18 лет, а у 21,6\%-дети старше 18 лет, 20\% приехали с родителями, 19,1\%-с братьями и сестрами (2017 г.). Азербайджанские мигранты, проживающие с детьми, в 90\% случаев (2017 г.) планируют дать им образование в России. Возможно, такие планы связаны с тем, что значительная доля детей, проживающих с родителями в России, лучше владеют русским языком, чем азербайджанским: 38,8\% отметили, что их дети лучше владеют русским языком и только 10,2\%- родным, 45,9\%- билингвы. Представители Средней Азии в меньшей степени связывают образование детей с Россией: около 70 \% выходцев из Киргизии, 84\%- из Узбекистана, $82 \%$ - из Таджикистана, живущих здесь с детьми.

Актуальный вопрос для работающих мигрантов-доступность детских садов и школ. Данные опроса говорят о благоприятной ситуации: у 22,4\% опрошенных дети ходят в детский сад (учитывались респонденты, имеющие детей младше 18 лет), при этом 50\% не нуждаются в этом ввиду возраста. Не смогли устроить детей в детский сад- 4,1\%. По сравнению с 2011 г. наблюдается положительная динамика (рис. 2). В сравнении с другими группами мигрантов, доступ детей азербайджанцев к услугам дошкольного образования довольно высок. Например, 8,2 \% таджиков, 
$13,1 \%$ узбеков и 14,9\% киргизов не смогли устроить своих детей в сады и ясли. В отличие от сферы занятости, более значительную роль, чем фактор легальности, в данном случае играет наличие мест в детских садах в районах проживания мигрантов, а также имеющаяся у них возможность отдать ребенка в частный детский сад.

Ходят ли Ваши дети в России в детсикй сад?

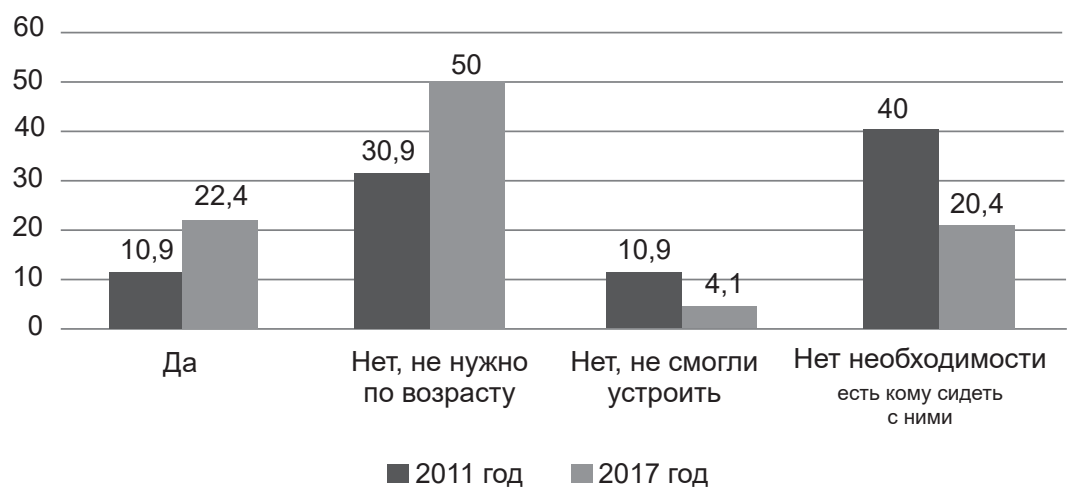

Рис 2. Посещение детских садов в 2011 и 2017 гг. детьми мигрантов из Азербайджана, в\% к опрошенным

Когда речь идет о долгосрочной миграции с детьми школьного возраста, очевидна необходимость их устройства в школу. У 57,1 \% опрошенных, имеющих детей до 18 лет, дети ходят в школу. Школьное образование для детей азербайджанских мигрантов является более доступным, чем дошкольное: всего 1\% не смог устроить детей в школу, хотя в 2011 г. таких было $7 \%$. По другим группам мигрантов не наблюдается значимых различий- доля тех, кто не смог устроить детей в школу не превышает $3 \%$ среди всех иностранных граждан.

\section{Жилищные условия}

Право каждого на жилище, как и на другие рассмотренные выше социальные права, закреплено в Конституции РФ (ст. 40) и в международных конвенциях. Но эта сфера жизни зависит, прежде всего, от уровня социально-экономического положения, доходов (право на получения жилья имеют только официально признанные нуждающимися граждане), доступности кредитов. В целом у мигрантов из Азербайджана складывается довольно благоприятная ситуация - $67 \%$ утверждают, что имеют отдельное жилье (дом или квартиру), у 23 \% - комната или часть квартиры, а всего 7,2\% и 0,5\% имеют комнату в общежитии или живут в вагончике, бытовке соответственно (2017 г.). Сравнительно хорошими жилищными условиями обладают также 
украинцы и армяне- 47,6 и 60\% имеют отдельную квартиру, а вот среди киргизов таких $36,3 \%$, среди узбеков- 32,6\%, среди таджиков- 36,3\%.

Среди азербайджанских мигрантов выросла доля имеющих собственное жилье: если в 2011 г. таких было 7,4\%, то в 2017-13,4\% (рис. 3). Это больше, чем среди приезжих из Армении (10\%), Украины (7,1\%), и особенно, из Таджикистана (3,4\%), Узбекистана (1,5\%), Киргизии (0,9\%). Кроме того, среди азербайджанцев сократилась доля живущих у родственников-с 10,4 до 6,4\%. Конечно, основная часть мигрантов арендует жилье, как с семьями, так и с другими людьми (не родственниками). В 2017 г. 59\% мигрантов из Азербайджана указали, что живут с семьей или с родственниками, 19,6\%-с другими людьми. Среди представителей стран Средней Азии с другими людьми (не родственниками) проживают в среднем около $35 \%$ респондентов.

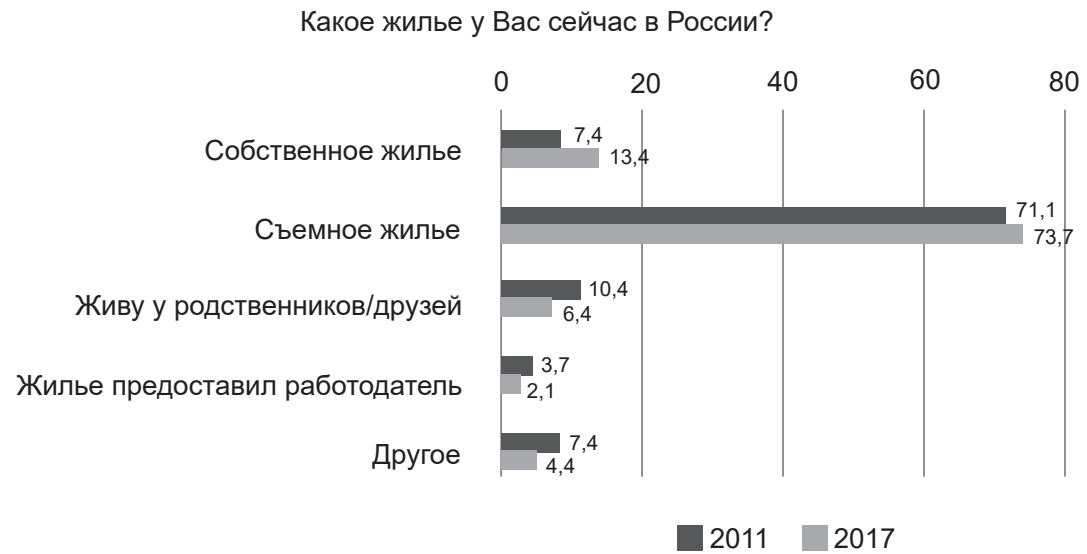

Puc. 3. Жилищные условия мигрантов из Азербайджана в 2011 и 2017 гг., в\% к опрошенным

Как видно, азербайджанцы в большей мере, чем другие мигранты обеспечены жильем, как арендуемым (отдельная квартира или дом), так и собственным. Среди них выше доля проживающих с родственниками и ниже-живущих с не родственниками. Это объясняется, с одной стороны, прочностью их родственных связей, с другой- более высокой, по сравнению с некоторыми группами мигрантов платежеспособностью.

\section{Заключение}

За счет изменения законодательства доступ мигрантов к социальным услугам в России в 2017 г. по сравнению с 2011 г. в некоторых сегментах улучшился. Более доступными стали медицинские услуги благодаря введению требования об обязательном медицинском страховании; образование детей, как начальное, так и среднее; жилищные условия, у азербайджанцев 
увеличилась доля имеющих собственное жилье. Однако среди азербайджанцев, в отличие от остальных групп мигрантов, увеличилась доля неформально занятых (работающих без договора). Это вкупе со сравнительно высокой долей работников без разрешительных документов делает азербайджанцев-мигрантов одной из наименее «легализованных» групп мигрантов на российском рынке труда. У них самый продолжительный рабочий день и, вследствие распространенности среди них неформальной занятости, трудовые права значительной их части могут быть не защищены.

Тем не менее неформальная и нелегальная занятость не оказывает значимого влияния на доступ азербайджанских мигрантов к социальным услугам- медицине, образованию детей, жилью. В этих сферах азербайджанцы ввиду относительно высокой платежеспособности не уступают мигрантам из других стран СНГ, либо имеют лучший доступ к социальным услугам.

\section{Список материалов для анализа}

Европейская сочиальная хартия от 03.05.1996 (пересмотренная).

Конституции Российской Федерации от 12.12.1993.

Международный пакт об экономических, социальных и культурных правах от 16.12.1966.

Постановление Правительства РФ (2013) Об утверждении Правил оказания медиизинской помощи иностранным гражданам на территории Российской Федерации № 186 от 06.03.2013.

Пояснительная записка (2014) K проекту федерального закона № 535567-6 om 24.11.2014. Доступно по ссылке: https://clck.ru/RPW23 (дата обращения: 20.05.2019).

Приказ Министерства образования и науки (2014) Об утверждении Порядка приема граждан на обучение по образовательным программам начального общего, основного общего и среднего общего образования № 32 от 22.01.2014.

Указание ЦБ РФ (2015) О минимальных (стандартных) требованиях к условиям и порядку осуществления медицинского страхования в части добровольного медиичинского страхования иностранных граждан и лии без гражданства, находящихся на территории российской федерации с иелью осуществления ими трудовой деятельности № 3793-У от 13.09.2015.

Федеральный закон (2012) Об образовании в Российской Федерации N 273-Ф3 от 29.12.2012.

Федеральный закон (2014а) О внесении изменений в Федеральный закон «О правовом положении иностранных граждан в Российской Федерации» и отдельные законодательные акты Российской Федерации № 357-ФЗ от 24.11.2014.

Федеральный закон (2014б) О внесении в Трудовой кодекс Российской Федераиии и статью 13 Федерального закона «О правовом положении иностранных граждан в Российской Федерации» изменений, связанных с особенностями регулирования труда работников, являющихся иностранными гражданами или лищами без гражданства № 409-ФЗ от 01.12.2014. 


\section{Список источников}

Бредникова О., Ткач О. (2010) Дом для Номады. Laboratorium. Журнал couиальных исследований, (3): 72-95.

Григорьева К.С., Мукомель В.И. (2014) Мигранты и россияне на рынке труда: условия, режим труда, заработная плата. В.И. Мукомель (ред.) Мигранты, мигрантофобии и миграционная политика. М.: Центральный Дом адвоката: 82-99.

Григорьева К.С., Мукомель В.И. (2016а) Новации в российском миграционном законодательстве в контексте правоприменения (начало). Миграционное право, (2): 3-10.

Григорьева К.С., Мукомель В.И. (2016b) Новации в российском миграционном законодательстве в контексте правоприменения (окончание). Мигращиионное право, (3): 3-9.

Карачурина Л. (2005) Мигранты и рынки труда крупных российских городов: согласование взаимных интересов. Демоскоn Weekly, 223-224. Доступно по ссылке: http://demoscope.ru/weekly/2005/0223/analit02.php (дата обращения: 22 мая 2019).

Кузнецова И.Б., Мухарямова Л. М. (2014) Трудовые мигранты в системе медицинских услуг: формальные и неформальные стратегии. Журнал исследований соииальной политики, 12 (1): 7-20.

Мукомель В.И. (2017) Мигранты на российском рынке труда: занятость, мобильность, интенсивность и оплата труда. Статистика и Экономика, (6): 69-79.

Омельченко Е.А. (2018) Образование и миграция в контексте повестки дня в области устойчивого развития до 2030 года. Современная Европа, (3): 49-59.

Росстат (2017) Мигращия, Международная мигращия. Доступно по ссылке: https:/ goo.gl/m6tyhD (дата обращения: 20 мая 2019).

Татарко А.Н. (2018) Социальный капитал и аккультурационные стратегии как факторы социокультурной адаптации мигрантов из Центральной и Средней Азии в московском регионе. Культурно-историческая психология, 14 (2): $33-43$.

Тюрюканова Е.В., Леденева Л.И. (2005) Ориентации детей мигрантов на получение высшего образования. Социологические исследования, (4): 94-100.

Эндрюшко А.А. (2018) Социально-экономический потенциал азербайджанских мигрантов, прибывших в Россию в 2014-2017 гг. Мониторинг общественного мнения: экономические и социальные перемены, (6): 216-233.

Aguilera M. B., Massey D. S. (2003) Social Capital and the Wages of Mexican Migrants: New Hypotheses pnd Tests. Social Forces, 82 (2): 671-701.

Entzinger H., Biezeveld R. (2003) Benchmarking in Immigrant Integration. Report for the European Commission. Rotterdam: ERCOMER.

Esser H. (2004) Does the 'New' Immigration Require a 'New' Theory of Intergenerational Integration? International Migration Review, 38 (3): 1126-1159.

Kashnitsky D., Demintseva E. (2018) 'Kyrgyz Clinics' in Moscow: Medical Centres for Central Asian Migrants. Medical Anthropology: Cross Cultural Studies in Health and Illness, 5 (37): 401-411.

Mingot S. E., Mazzucato V. (2019) Moving for a 'Better Welfare'? The Case of Transnational Sudanese Families. Global Networks, 19 (2): 139-157.

Penninx R. (2019) Problems of and Solutions for the Study of Immigrant Integration. Comparative Migration Studies, 7 (13): 2-11. 
Anna Endryushko

\section{MIGRANT ACCESS TO SOCIAL SERVICES IN RUSSIA: THE CASE OF AZERBAIJANIS}

This article examines access to social services for migrants from Azerbaijan in 2017 compared to 2011, as well as changes to the level of access in the aftermath of reform to migration legislation in 2013-2016. As the main indicators for analysis, we chose the legality of work, working conditions, medical services, education of children, and housing conditions of Azerbaijani migrants in comparison with migrants from other CIS countries. The empirical base of the study was data from a nationwide survey of migrants in 2011 and 2017. We also used data from semi-structured interviews with experts. The study showed that migrants from Azerbaijan, being one of the least regulated groups in the Russian labour market, have the same level of access to social services as migrants from other CIS countries. Due to the high level of informal and irregular employment, cases of violation of labour rights are still widespread. However, due to high financial solvency in comparison with other migrants, Azerbaijanis have equal or better access to health care, children's education and housing conditions. This is because, first, they are more likely than others to apply for paid medical services. Secondly, Azerbaijani migrants have wider access to preschool institutions in Russia in comparison with immigrants from Central Asia, and to general education institutions they are at the same level as other migrants. Third, Azerbaijanis are provided with separate housing, including their own, more than other groups of migrants. It is concluded that in 2017, compared to 2011, access of migrants in general, including Azerbaijanis, to social services has improved. Some of these changes are related to the amendments to the migration legislation in 2013-2016.

Key words: labour migrants, Azerbaijanis, social services for migrants, migration legislation

DOI: DOI: 10.17323/727-0634-2020-18-4-689-704

\section{References}

Aguilera M. B., Massey D. S. (2003) Social Capital and the Wages of Mexican Migrants: New Hypotheses and Tests. Social Forces, 82 (2): 671-701.

Brednikova O., Tkach O. (2010) Dom dlja Nomady [What Home Means to Nomads]. Laboratorium. Zhurnal social'nyh issledovanij [Laboratorium. Journal of Social Research], (3): $72-95$.

Anna A. Endryushko- Junior Research Fellow, Federal Center of the Theoretical and Applied Sociology, Russian Academy of Sciences, Moscow, Russian Federation. Email: anna.endryushko@mail.ru 
Endryushko A.A. (2018) Social'no-ekonomicheskij potencial azerbajdzhanskih migrantov, pribyvshih v Rossiyu v 2014-2017 gg. [Social and Economic Potential of Azerbaijani Migrants Who Entered Russia in 2014-2017]. Monitoring obshchestvennogo mneniya: ekonomicheskie i social'nye peremeny [Monitoring of Public Opinion: Economic and Social Changes], (6): 216-233.

Entzinger H., Biezeveld R. (2003) Benchmarking in Immigrant Integration. Report for the European Commission. Rotterdam: ERCOMER.

Esser H. (2004) Does the 'New' Immigration Require a 'New' Theory of Intergenerational Integration? International Migration Review, 38 (3): 1126-1159.

Grigor'eva K.S., Mukomel' V.I. (2014) Migranty i rossiyane na rynke truda: usloviya, rezhim truda, zarabotnaya plata [Migrants and Russians in the Labour Market: Conditions, Labor Regime, Wages]. In: V.I. Mukomel» (ed.) Migranty, migrantofobii i migracionnaya politika [Migration, Migrantophobia and Migration Policy]. Moscow: Central'nyj Dom advokata: 82-99.

Grigor'eva K.S., Mukomel' V.I. (2016a) Novacii v rossijskom migracionnom zakonodatel'stve v kontekste pravoprimeneniya (nachalo) [Innovations in Russian Migration Legislation in the Context of Law Enforcement (beginning)]. Migracionnoe pravo [Immigration Law], (2): 3-10.

Grigor'eva K.S., Mukomel' V.I. (2016b) Novacii v rossijskom migracionnom zakonodatel'stve $\mathrm{v}$ kontekste pravoprimeneniya (okonchanie) [Innovations in Migration Legislation in the Context of Law Enforcement (end)]. Migracionnoe pravo [Immigration Law], (3):3-9.

Karachurina L. (2005) Migranty i rynki truda krupnyh rossijskih gorodov: soglasovanie vzaimnyh interesov [Migrants and Labour Markets of Large Russian Cities: Coordination of Mutual Interests]. Demoskop Weekly, 223-224. Available at: http://demoscope.ru/ weekly/2005/0223/analit02.php (accessed: 27.05.2019).

Kashnitsky D., Demintseva E. (2018) 'Kyrgyz Clinics' in Moscow: Medical Centres for Central Asian Migrants. Medical Anthropology: Cross Cultural Studies in Health and Illness, 5 (37):401-411.

Kuznecova I. B., Muharjamova L.M. (2014) Trudovye migranty v sisteme medicinskih uslug: formal'nye i neformal'nye strategii [Migrant Workers in the Health Care System: Formal and Informal Strategies]. Zhurnal Issledovanii Sotsial'noi Politiki [The Journal of Social Policy Studies], 12 (1): 7-20.

Mingot S.E., Mazzucato V. (2019) Moving for a 'Better Welfare'? The Case of Transnational Sudanese Families. Global Networks, 19 (2): 139-157.

Mukomel' V.I. (2017) Migranty na rossijskom rynke truda: zanyatost', mobil'nost', intensivnost' i oplata truda [Migrants in the Russian Labour Market: Employment, Mobility, Intensity and Wages]. Statistika i Ekonomika [Statistics and Economics], (6): 69-79.

Omel'chenko E.A. (2018) Obrazovanie i migracija v kontekste povestki dnja v oblasti ustojchivogo razvitija do 2030 goda [Education and Migration in the Context of the 2030 Sustainable Development Agenda]. Sovremennaja Evropa [Modern Europe], (3): 49-59.

Penninx R. (2019) Problems of and Solutions for the Study of Immigrant Integration. Comparative Migration Studies, 7 (13): 2-11. 
Rosstat (2017) Migraciya. Mezhdunarodnaya migraciya [Migration. International Migration]. Available at: https://goo.gl/m6tyhD (accessed: 27.05.2019).

Tatarko A. N. (2018) Social'nyj kapital i akkul'turacionnye strategii kak faktory sociokul'turnoj adaptacii migrantov iz Central'noj i Srednej Azii v moskovskom regione [Social Capital and Acculturation Strategies as Factors of Socio-Cultural Adaptation of Migrants from Central and Central Asia in the Moscow Region]. Kul'turno-istoricheskaya psikhologiya [Cultural-historical Psychology], 14 (2): 33-43.

Tjurjukanova E. V., Ledeneva L.I. (2005) Orientacii detej migrantov na poluchenie vysshego obrazovanija [Orientation of Migrant Children to Higher Education]. Sociologicheskie issledovanija [Sociological Studies], (4): 94-100. 